\title{
Consumer Perceptions of Influencer Marketing: Application of Q Methodology and Implications for Business Communication
}

\author{
Jooyun Hwang ${ }^{1}$, Sejung $\mathrm{Oh}^{2}$, Siyeon Jang ${ }^{3}$ \\ 'Strategic Communications, School of Communication, Elon University, Elon, NC, USA \\ ${ }^{2}$ Hankuk University of Foreign Studies, Seoul, Korea \\ ${ }^{3}$ Media Data Lab, Hankuk University of Foreign Studies, Seoul, Korea
}

Objectives: As a way to interact with consumers, social media influencers (SMIs) are getting popularity among brands. Therefore, it is very important to understand how influencers are perceived by audiences for the success of influencer marketing. The purpose of this study is to identify consumer types according to their perceptions of SMIs and influencer marketing.

Methods: Q methodology was conducted on 23 people, including 11 females and 12 males, who are mostly in their twenties, living in South Korea. A total of 46 statements collected from various sources regarding the study topic was sorted by each participant into three groups of "agree," "disagree," or "neither agree, nor disagree (neutral)" piles. Data, then, were analyzed using Varimax rotation and factor analysis by QUANL program.

Results: This study identified four different consumer groups based on the participants' perceptions of and expectations for influencers and influencer marketing. Influencers are labeled as "Advertising tool," "Entertainer," "Information source" and "Tastemaker," respectively.

Conclusions: This study observed various reasons of why and how people consume social media content which is created by influencers and brands. While some expect influencers and their marketing to be authentic and transparent, others simply consume influencer content on social media for entertainment purposes. Different marketing strategies are recommended to meet a particular group's needs and expectations for influencers in order to maximize the effectiveness of business communication.

Key Words: Q Methodology, Influencer, Influencer Marketing, Social Media, Consumer Types

Received: Mar 8, 2021 Revised: Jun 15, 2021 Accepted: Jul 2, 2021

Corresponding author: Jooyun Hwang

Strategic Communications, School of Communication, Elon University, Elon, NC, USA

Tel: +1-352-262-7214, E-mail: jhwang@elon.edu

This is an Open Access article distributed under the terms of the Creative Commons Attribution Non-Commercial License (http://creativecommons.org/licenses/ by-nc/4.0/) which permits unrestricted non-commercial use, distribution, and reproduction in any medium, provided the original work is properly cited.

Copyright $\odot 2021$ Korean Association for Business Communication.

\section{Introduction}

As the popularity of various forms of social media have increased, consumers' purchasing decisions have been largely affected by social media influencers (SMIs). Market research conducted in 2012 reported that people are $71 \%$ more likely to make a purchase if the product or service is referred on social media (Brackett, 2012). In 2017, Forbes, a global media company, also reported that social media serves a major factor for millennials when it comes to buying fashion and beauty products. Obviously, the marketing initiatives involving SMI have been 
mainstream due to the constantly evolving and changing market. The impact of the SMIs has been most notable in East Asia. In South Korea, where $83 \%$ of the population is active users of social networks, nearly $61 \%$ of shoppers reported that they interact with SMIs at least once a day, and 35\% of them interact with influencers more than twice a day to inform their buying decisions (Rakuten Marketing, 2019).

SMIs can be defined as third-party endorsers who affect an audience's attitudes and behaviors (Freberg, Graham, McGaughey, \& Freberg, 2011) through various media platforms such as blogs, Twitter, Instagram, and YouTube. Influencer marketing, therefore, refers to a brand's communication and promotion practice involving key individuals who can exert influence over potential customers (Brown \& Hayes, 2008). Due to the influencers' ability to reach a sizeable social network of people following them (De Veirman, Cauberghe, \& Hudders, 2017), more and more companies/brands have used SMIs in their marketing to create an opportunity to market their products and services to a targeted group of people.

Although SMIs are gaining popularity among brands as a way to interact with its consumers and to propel its brand on social media, there have been some downsides to influencer marketing, which requires further examination. Consumers nowadays are skeptical about brand driven advertising (De Veirman et al., 2017), and they are relying on fellow consumers more than ever to inform them regarding their purchasing decisions. Moreover, such advancement of technologies as ad-blocking software helps consumers skip or even avoid commercials (Fransen et al., 2015; Kaikati \& Kaikati, 2004). Furthermore, unethical behaviors of some SMIs have raised questions about the effectiveness of influencer marketing. Such scandals include, but are not limited to an influencer's fake followers, culturally and racially insensitive remarks, use of inappropriate or no language to indicate sponsorship, and violation of influencer guidelines (e.g., FTC guidelines for influencers and brand) (Mediaix, 2021). This caused media buzz around the world, and influencer marketing has become one of the hot topics of debate worldwide, including in South Korea (Chae, 2018).

With the aforementioned background and issues in mind, this study aimed at understanding how influencers are perceived by different audience groups. While this topic has mainly been researched from the perspectives of marketing practitioners in the past, most academics and business practitioners would agree that influencer marketing is a customer-centric concept. Therefore, verifying audience perceptions of influencers is significant for the success of influencer marketing. Indeed, about a decade ago, Freberg et al. (2011) suggested to further examine how the SMIs are perceived by audiences because the right influencer can contribute to an organization's bottom line. More recently, Djafarova and Rushworth (2017) suggested that brands must consider more customized strategies in using influencers so that they can be more effective in appealing to a particular consumer group. In order to fill this academic gap, the purpose of this study is to apply Q methodology and understand consumers' subjective viewpoints towards influencer marketing in South Korea.

\section{Theoretical Framework}

\section{Growth of Social Media and Influencer Marketing}

Changes in media use among consumers require brands to rethink which media to choose to effectively communicate their messages. According to the Uses and Gratification theory (Katz, Haas, \& Gurevitch, 1973; McQuail, 1983), people actively seek out specific media contents to satisfy their needs: personal relationships, personal identity, surveillance and diversion. Among them, diversion, which refers to seeking media for "entertainment, or tension release needs," becomes a useful factor for marketers to strategically covey their marketing messages on social media such as YouTube.

Launched in 2005, YouTube is a video sharing platform offering the opportunity to create and share content to a diverse and global audience. With more than 48,000 hours worth of video uploads and views per week (Perrin \& Anderson, 2019), YouTube is the second-largest search engine in the world right behind Google (Wagner, 2017). Especially in South Korea, more than $83 \%$ of citizens spend 17 days per month watching YouTube, implying that 43 million people watch YouTube more than 30 hours per month (Oh, 2020). This is where the influencers come in to play in social media marketing. Collaborating with influencers, brands use YouTube to showcase their products/services, create "how to" tutorials to help customers, integrate customer testimonials into their marketing plans, and so forth. While brands are still conveying their marketing messages through different types of contents on YouTube, people are entertained and relaxed by watching them (Khan, 2017).

Instagram is another fastest growing mediums in social media marketing. Launched in 2010, Instagram has become a great potential of online shopping since it allows marketers to actively interact with their consumers by sharing photographs and videos. Jang and Kim (2019) identified four characteristics of social network sites (SNS) in South Korea: homogeneity, commonality, rapidness \& reliability, and customization. Among the four characteristics, rapidness \& reliability and homogeneity showed significant influence on purchase intention on the Instagram market when shopping for clothing. As the use of social media 
continues to increas, and the power of SMIs grows, the following three factors have been identified as critical to the success of influencer marketing.

\section{Authenticity}

For a brand, influencer marketing begins with marketing directly to influencers, which consists of identifying and targeting influencers who can best represent its brand identity. The brand, then, works with the influencers to eventually elicit a specific action from its targeted customers through their social media activities. One of the factors that determine the success of influencer marketing is authenticity.

Authenticity is defined as "the feeling and practice of being true to one's self or others" (Vannini \& Franzese, 2008, p. 1621). In influencer marketing, authenticity occurs when recipients of the message can identify the message with the influencer (Brown, Kozinets, \& Sherry, 2003). Wiley (2014) noted that bloggers have become an important source of information to consumers because they are deemed to be more authentic and accessible than traditional celebrities. In the era of social media, consumers are attracted more to a SMI's content than to marketing messages because an influencer's contents are deemed non-commercial in nature. As a result, a SMI's content is perceived as more trustworthy, real and authentic than brand-oriented messages (Mudambi \& Schuff, 2010; Scott, 2015).

Research on authenticity found that authenticity of an influencer can positively enhance a consumer's perception of product quality and evaluation (Moulard, Raggio, \& Folse, 2016). A recent study by Pöyry, Pelkonen, Naumanen, and Laaksonen (2019), which examined audience responses to social media endorser's characteristics, observed that authenticity positively increases followers' attitudes towards photos (both sponsored and non-sponsored) and purchase intentions for sponsored photos on Instagram. Findings from previous research suggest that if an influencer's content is authentic and honestly reflects his/her personal life and values even in sponsored messages, then it can enhance communication effectiveness, because consumers perceive it as real and transparent.

\section{Source Credibility}

Source credibility research suggested that an endorser's attractiveness, trustworthiness and expertise affect the effectiveness of endorsers and their messages (Dholakia and Sternthal, 1977; Ohanian, 1991; Solomon, 1996). This holds especially true for influencers who are active on social media such as YouTube and Instagram (Munnukka, Maity, Reinikainen, \& Luoma-aho, 2019). Among the various factors that may affect an endorser's credibility, research has observed that the perceived trust- worthiness of an endorser matters more than one's expertise (Hovland, Janis, \& Kelley, 1953; Ohanian, 1991) in enhancing message effectiveness.

A recent study examining consumers' perceptions of SMIs in the luxury fashion industry suggested that trustworthiness has the most impact on brand perception, image and trust. Interestingly, this study observed that an influencer's expertise exerted almost zero impact on the brand perception constructs (Wiedmann \& von Mettenheim, 2020). An endorser's trustworthiness can be achieved through conveying the information in a truthful way. A recent focus group study of Generation X and Y (Čop \& Culiberg, 2020) found that when an influencer who is not an expert in one field "acts as an expert," it is considered frivolous. As noted by Byrne, Kearney, and MacEvilly (2017), consumers even felt that influencers were being "deceptive" when they shared misleading and dishonest information. This, in turn, generates negative attitudes or behaviors toward a message and the sources of the message (Friestad \& Wright, 1994; Paek, Murthy, Hahn, \& Zhong, 2009).

\section{Sponsorship Disclosure}

First noted by Balasubramanian (1994), sponsored content refers to paid collaborations between brands and influencers, including the ones on social media (De Veirman et al., 2017). An influencer creates and publishes contents on social media, recommending products/services for a brand and in turn, receives compensation from the sponsoring brand. Compensation may take different forms, ranging from free samples and, coupons to cash (Lu, Chang, \& Chang, 2014). Past research has identified various types of sponsored content, which includes simple disclosure (e.g." "this content is sponsored"), and the one with additional information indicating an influencer's honest opinion about the sponsored content (Hwang \& Jeong, 2016), or disclosing the type of compensation the influencer received from a sponsored brand (Lu et al., 2014).

There have been growing concerns on sponsorship disclosure because if there is no clear indication about the sponsorship discourse, users may not recognize the commercial intent of influencers. In order to avoid misleading consumers, The Federal Trade Commission (FTC) in the United States has authorized that sponsorship disclosure must be indicated in the content if the content is sponsored by a third-party source. In 2019, FTC released a new publication on sponsorship disclosure for influencers. This new guide, "Disclosures 101 for Social Media Influencers," clearly states that influencers "cannot assume that followers are aware of their connections to brands" (FTC, 2019), highlighting the responsibility that influencers must take in terms of revealing their relationship to a brand. In order to 
make sponsorship disclosures necessary, the FTC guidelines provide SMIs with the languages that influencers might use, as well as where in their social posts a disclosure should appear.

Lee and Kim (2020), for instance, tested if the use of different types of sponsorship disclosure language has any effect on the activation of persuasion knowledge. The study, which compared three types of languages - explicit sponsorship disclosure language (e.g., "Sponsored" and "Advertising"), implicit disclosure language (e.g., "sp" and "ad"), and no disclosure and observed no clear differences on the recognition of advertising messages. Social media users nowadays are more prone to instantly recognize promotional messages on social media because seeing content creators collaborating with brands has become more routine on social media (Lee \& Kim, 2020).

Others have further examined the impact of sponsorship disclosure on a consumer's decision-making process, which observed some negative impact of sponsorship disclosure in various contexts. Colliander and Erlandsson (2015), for instance, found that a sponsorship disclosure on a sponsored blog negatively affected the perceived credibility of and attitude toward the blog and the blogger. When comparing the effects of sponsorship disclosure in television shows and blogs, Campbell, Mohr, and Verlegh (2013) found that the disclosure of sponsorship in both mediums negatively affected users' attitudes toward the brand. Similarly, van Reijmersdal et al. (2016) also observed that sponsorship disclosure in blogs evoked a user's cognitive and affective resistance against the sponsored content.

However, disclosing sponsorship compensation justification may positively affect a consumer's responses to the sponsored content. A recent study observed that people who are exposed to be compensated by a sponsorship showed more positive attitudes toward influencers, who were seen as a more credible information source compared to those in a simple sponsorship disclosure condition (Stubb, Nyström, \& Colliander, 2019). While a sponsorship disclosure cue informs a viewer that the content is sponsored by a third-party source, a sponsorship compensation justification provides more insight on why influencers are partnering or collaborating with brands and being paid to promote those brands.

Although past research has demonstrated the impact of sponsorship disclosure on users' decision making process, they typically relied on quantitative methods such as Likert scale surveys or experiments. While useful in quantifying consumers' attitudes towards a brand and buying intentions, little is known about how consumers draw inferences about influencers' marketing motives and goals (Boush, Friestad, \& Rose, 1994; Friestad \& Wright, 1994; Kirmani \& Wright, 1989). Therefore, more attention is required to understand the meanings and motiva- tions behind a consumer's decision-making process (McKeown, 2001), which this study aims to address.

\section{Methods}

\section{Q. Methodology}

This study applied Q methodology to understand the diversity of subjectivity toward the influencer and influencer marketing. Q methodology has been getting more attention in academia because it is useful to identify subjective attitudes, opinions, viewpoints and beliefs for a particular topic (e.g., Cross, 2005; Stanton \& Guion, 2010). Song and Ko (2017), for instance, used Q methodology and identified consumer groups based on their perceptions towards the sustainability in the fashion industry and provided practical implications when segmenting target audiences. As such, Q methodology is considered particularly suitable for this topic, because it provides a "basis for measurement of feelings, attitudes, opinions, thinking, fantasy, and all else of a subjective nature" (Stephenson, 1967, p. 11).

Using this method, the current study asked the research participants to sort 46 statements on a nine-point most-agree/ most-disagree scale to reflect their own subjective attitudes towards the topic. A factor analysis was followed across people to uncover diverse and different patterns of thoughts with small samples. Findings from Q methodology, therefore, highlight how and why people make the decisions they do (Valenta \& Wigger, 1997), which serves as a great foundation for further investigating the topic with larger samples for generalization (e.g., Song \& Ko, 2017).

\section{Q Sample}

Q sample, also known as Q statements, refers to the sample of statements drawn from a variety of sources. According to Stephenson (1967), Q statements should represent a "concourse," which refers to a sum of various opinions, perspectives, or statements around the research topic being investigated. To meet this purpose, Q statements for this study were gathered from several sources. First, in-depth interviews with 6 people of the relevant population were conducted to understand the following: general social media usage behaviors, perceptions of SMIs and the content they upload on social media, social media engagement behaviors and the criteria for following others including influencers, perceptions of influencer marketing its impact on consumer behaviors and so forth. Secondly, besides interviews, such sources as academic literature, news and comments on social media regarding SMI and influencer marketing were used to form $\mathrm{Q}$ statements.

A total of 135 Q populations were collected based on the di- 
rect quotations and themes emerged from the interviews and statements from the secondary sources. Two researchers, then, reviewed the $135 \mathrm{Q}$ statements and eliminated the statements that were vague, redundant or similar in order to achieve "brevity, clarity, and representativeness" (Seo, Kim, \& Seo, 2011). Finally, a total of 46-statement Q samples (Table 1) was prepared for the study. According to Shinebourne (2009), a set of between 40 to 80 statements meets the acceptable range of $Q$ samples.
P Sample

P sample refers to research participants, and consists of 23 participants, which includes 11 females. The participants were recruited because they had used social media such as Instagram, YouTube and Facebook, and had heard of the term "influencer" before. The majority of the participants were in their twenties, while 2 were in thirties and 1 in their forties. As the Q methodology is used to reveal the dimensions of subjectivity from

Table 1. Array of Z-scores for each factor type

\begin{tabular}{|c|c|c|c|c|}
\hline Q sample & F1 & F2 & F3 & F4 \\
\hline 1.I tend to enjoy watching product reviews by influencers on Youtube. & -1.5 & 0.8 & 0.7 & -1.3 \\
\hline 2. I tend to enjoy watching beauty tips and 'how to $\sim^{\prime}$ contents uploaded by influencers on Youtube. & -1.7 & 1.3 & -0.0 & -1.3 \\
\hline 3. I think that Instagram is better than Youtube for getting shopping information. & -0.1 & -1.3 & -1.3 & 1.2 \\
\hline 4. I usually follow the influencers of my interests rather than following my friends on Instagram. & -0.7 & $-0,5$ & -1.0 & -1.3 \\
\hline $\begin{array}{l}\text { 5. I tend to place more trust in the product/service information provided by influencers than in those provided by } \\
\text { companies (or brands). }\end{array}$ & -1.3 & -0.3 & 0.5 & 1.2 \\
\hline $\begin{array}{l}\text { 6. I have more trust in the product/service information provided by the influencers who became famous in } \\
\text { Youtube or Instagram than in those provided by the celebrities who are wellknown to the public, like singers } \\
\text { or actors. }\end{array}$ & -1.2 & -0.1 & 0.2 & -1.3 \\
\hline $\begin{array}{l}\text { 7. I do not like celebrities or influencers who excessively expose sponsored products/services in their own social } \\
\text { media (SNS). }\end{array}$ & 1.4 & -1.4 & 0.2 & -0.7 \\
\hline $\begin{array}{l}\text { 8. I think that the information on SNS provided by ordinary people, even though they are not influencers, affects } \\
\text { me when I purchase or use products/services. }\end{array}$ & 0.4 & 1.4 & 1.9 & -1.1 \\
\hline $\begin{array}{l}\text { 9. I do not tend to perceive the promotion of products/services as advertisements because Youtube contents } \\
\text { have a certain viewing time and get combined with the stories told by creators. }\end{array}$ & -1.1 & -0.2 & -0.7 & 0.8 \\
\hline $\begin{array}{l}\text { 10. I tend to react negatively when I watch influencers with insufficient expertise in particular products/services } \\
\text { explaining as if they were experts in those areas. }\end{array}$ & 0.5 & -1.3 & 1.1 & -0.6 \\
\hline $\begin{array}{l}\text { 11. I tend to react negatively if wellknown celebrities, like singers or actors, write reviews about particular } \\
\text { products/services on Instagram because it seems to me that they are sponsored by those products/services. }\end{array}$ & 0.0 & -1.3 & -0.1 & -05 \\
\hline 12.I think that the popularity of influencers is proportional to the number of their followers. & 0.2 & 0.5 & 0.3 & -0.1 \\
\hline $\begin{array}{l}\text { 13. If there are products that I become interested in among the products introduced by influencers, I tend to } \\
\text { decide whether to purchase them after visiting the store and experiencing them. }\end{array}$ & 0.1 & -0.7 & 0.3 & -0.6 \\
\hline 14. I prefer to purchase products using the promotion codes (recommender's codes) provided by influencers. & -1.3 & -0.4 & -1.5 & -1.2 \\
\hline $\begin{array}{l}\text { 15. I tend to be generally satisfied after I use the products or visit famous places or restaurants introduced by } \\
\text { influencers. }\end{array}$ & -0.9 & -0.2 & -1.1 & -0.8 \\
\hline $\begin{array}{l}\text { 16. I do not entirely trust influencers' evaluations because I think that they are people who advertise particular } \\
\text { brands or places with some compensation. }\end{array}$ & 1.6 & -0.5 & -1.4 & -0.1 \\
\hline $\begin{array}{l}\text { 17. I think I become more eager to experience or purchase something if I watch the photos or images provided } \\
\text { by influencers; probably because they present products/services or places in more stylish ways compared to } \\
\text { ordinary people. }\end{array}$ & -0.4 & 1.3 & 0.1 & 0.0 \\
\hline $\begin{array}{l}\text { 18. I tend to refer more to the product/service reviews provided on SNS by ordinary people (or little-known } \\
\text { influencers) rather than influencers. }\end{array}$ & 1.0 & 1.2 & -0.7 & 0.6 \\
\hline $\begin{array}{l}\text { 19. If I become interested in brand names (hash tags, SNS account) exposed by influencers when they present } \\
\text { the photos of the sponsored products/services, I tend to visit those brand accounts and follow or search those } \\
\text { products/services. }\end{array}$ & -0.5 & -1.3 & -0.0 & -0.2 \\
\hline $\begin{array}{l}\text { 20. If I find out that they upload contents on their SNS for advertising products/services without reflecting their } \\
\text { own daily life (real experience), I might get to doubt their sincerity and dislike those influencers. }\end{array}$ & 1.1 & -1.4 & 1.3 & -1.2 \\
\hline $\begin{array}{l}\text { 21. I have the intention of purchasing products/services from companies that conduct marketing through } \\
\text { influencers. }\end{array}$ & -0.5 & -0.1 & -0.8 & 1.1 \\
\hline
\end{tabular}


Table 1. Continued

\begin{tabular}{|c|c|c|c|c|}
\hline Q sample & F1 & F2 & F3 & F4 \\
\hline 22. I have frequent experiences of impulse-buying after watching product reviews by influencers. & -1.7 & -2.0 & -1.0 & 0.4 \\
\hline $\begin{array}{l}\text { 23. I do not think that the impact of influencers can be ignored even though there are various channels for } \\
\text { getting information on products/services. }\end{array}$ & 1.1 & 1.0 & 1.3 & 1.1 \\
\hline $\begin{array}{l}\text { 24. I have frequent experiences of getting disadvantaged due to purchasing the products/services recommended } \\
\text { by influencers. }\end{array}$ & -1.5 & -1.3 & -0.3 & -0.9 \\
\hline $\begin{array}{l}\text { 25. I think that influencers make an impact on the intention to purchase particular products/services based on } \\
\text { how persuasively they explain the reviews of products/services. }\end{array}$ & 0.2 & 1.1 & 1.4 & 1.7 \\
\hline $\begin{array}{l}\text { 26. I do not think that there is much difference between socalled influencer marketing and conventional } \\
\text { advertisements that use models in order to introduce products/services. }\end{array}$ & 0.6 & 0.7 & -0.6 & 0.4 \\
\hline $\begin{array}{l}\text { 27. I do not think that using influencers who are less known to the public, as opposed to celebrities, as advertising } \\
\text { models is particularly effective for raising brand awareness or increasing sales of the products. }\end{array}$ & -0.5 & -0.5 & -1.4 & 1.1 \\
\hline $\begin{array}{l}\text { 28. I think that it is the influencers' duty to announce their sponsorship accurately when they share reviews of } \\
\text { products/services. }\end{array}$ & 1.6 & 1.6 & 2.3 & -1.0 \\
\hline $\begin{array}{l}\text { 29. I often doubt whether the reviews of products/services shared by influencers are based on their real } \\
\text { experiences. }\end{array}$ & 0.9 & 0.4 & 0.6 & 0.7 \\
\hline $\begin{array}{l}\text { 30. I tend to become interested or purchase products/services due to getting attracted to the brand itself rather } \\
\text { than the reviews uploaded by influencers. }\end{array}$ & 0.8 & 1.0 & 0.1 & -1.6 \\
\hline 31. I have more trust in foreign influencers. & -1.3 & -0.3 & -1.5 & -2.1 \\
\hline 32. I have more trust in the influencers with relatively more followers. & -0.5 & 0.4 & -0.8 & -0.3 \\
\hline $\begin{array}{l}\text { 33. I think that introducing products/services through influencers can raise brand awareness but cannot increase } \\
\text { trust in those products/services. }\end{array}$ & 1.5 & 0.2 & 0.7 & 0.2 \\
\hline $\begin{array}{l}\text { 34. I think that if influencers get involved in sales beyond advertising products/services, then they are no different } \\
\text { from show hosts at home-shopping channels. }\end{array}$ & 0.9 & 1.2 & -0.1 & -1.1 \\
\hline $\begin{array}{l}\text { 35. I think that influencers encourage unnecessary consumption using the mentality that people wish to imitate } \\
\text { those they envy. }\end{array}$ & 0.0 & -0.9 & -0.7 & -0.5 \\
\hline $\begin{array}{l}\text { 36. I am worried that if influencers go so far as selling products/services, they might focus on delivering } \\
\text { information to attract people to purchase rather than providing honest evaluations. }\end{array}$ & 1.6 & 0.9 & -0.7 & 1.0 \\
\hline $\begin{array}{l}\text { 37. If particular platforms (including Instagram, Youtube) are frequently used for brand promotion or product } \\
\text { sales for companies or influencers, I might feel averse to using those platforms. }\end{array}$ & 0.8 & -1.1 & 0.4 & 1.1 \\
\hline $\begin{array}{l}\text { 38. I might react negatively to the brand as well as influencers if the impact of influencers is used in an excessively } \\
\text { commercial manner. }\end{array}$ & 1.4 & -1.2 & 0.8 & 0.2 \\
\hline 39. I think that it is a positive thing for popular influencers to launch their own brand and do their marketing. & 0.0 & 1.1 & -0.8 & 1.0 \\
\hline $\begin{array}{l}\text { 40. I tend to trust and purchase the products recommended by influencers because I frequently watch the daily } \\
\text { life of influencers and communicate with them through Instagram or Youtube, and thus feel like their friend. }\end{array}$ & -1.8 & -0.8 & -1.5 & -0.5 \\
\hline $\begin{array}{l}\text { 41. I think that appropriate regulations (including disclosure of sponsorship, restriction of direct sales) are } \\
\text { necessary for influencer marketing. }\end{array}$ & 0.0 & -0.1 & 1.9 & 1.0 \\
\hline $\begin{array}{l}\text { 42. I do not tend to trust brands that use influencer marketing unconditionally without building their own brand } \\
\text { images. }\end{array}$ & 0.9 & 0.2 & 0.7 & 0.8 \\
\hline $\begin{array}{l}\text { 43. I might have difficulties in writing negative reviews for products/services recommended or being sold by the } \\
\text { influencers with whom I have established intimacy. }\end{array}$ & 0.0 & -0.9 & -1.0 & 0.5 \\
\hline 44. If the influencers who I like advertise particular brands, I seem to form positive images of those brands. & -0.4 & 1.4 & 0.4 & 1.9 \\
\hline 45. I think that it is a positive strategy for a brand to launch their products in collaboration with influencers. & 0.6 & 0.8 & 0.1 & 1.7 \\
\hline $\begin{array}{l}\text { 46. I think that the priority should be given to building trust between influencers and followers (consumers) } \\
\text { rather than the popularity of influencers in order for influencer marketing to be effective. }\end{array}$ & -0.5 & 1.5 & 1.8 & 1.6 \\
\hline
\end{tabular}

an individual's intrinsic perspective, Q research is typically performed on small samples (Valenta \& Wigger, 1997).

\section{Q Sorting}

Participants were first asked to sort a set of 46 statements into three groups of "agree," "disagree," or "neither agree, nor 
disagree (neutral)" piles. Participants then further sorted the statements within each pile according to the predetermined, quasi normal distribution pattern (Andrews, Drennan, \& Russell-Bennett, 2012; Shinebourne, 2009). For the "agree" pile, for example, participants first chose two statements they agreed with the most ( +6 column in the pattern) followed by selecting three statements they agreed with to a slightly lower degree of agreement ( +5 column). Participants proceeded until all the statements in the "agree" pile ran out. Participants repeated the procedure for "disagree" and "neutral" piles.

\section{Statistical Analysis}

A principal component analysis using Varimax rotation by QUANL program was used to analyze the data, resulting in four types. The eigen value was above 1 , indicating that all results were meaningful with $50 \%$ explanatory power (Table 2 ). The Eigen value for each type is also shown in Table 2. Individual responses to each statement were inter-correlated in a $46 \times 46$ correlation matrix. As shown in Table 3, Types 1 and $3(r=0.38)$ showed a high inter-correlation, as did Types 1 and $4(\mathrm{r}=0.35)$. The higher value of correlation of each type in traditional or R-methodology indicates higher inter-correlation between the types. However, the higher inter-correlation between the types in Q methodology "does not indicate less difference between the types" (Song \& Ko, 2017, p. 266).

\section{Results}

Four factors were identified regarding consumers' perceptions of influencer marketing. A label was assigned to each type based on the Q-statements that had significant factor scores. The demographic information of each group's participants is described in Table 4. Table 1 shows 46 statements with $\mathrm{Z}$ scores on each of the four types.

\section{Type 1: Influencer as an Advertising Tool}

Type 1 shows the most negative perception of influencer marketing. For Type 1, influencers are just one of the advertising tools, who promote their contents for any sort of compensation (e.g., monetary compensation or gifts from the companies) (\#16). Therefore, Type 1 does not fully trust the content provided by influencers, because they consider those contents to be paid commercials. Type 1, therefore, rather trusts information from laypeople or relies on experts when looking for information on a particular subject. For Type 1, IM can be effective to increase brand awareness. It, however, does not make them trust products/ services promoted by an influencer (\#33 and 5) and eventually won't affect their purchase intentions (\#22, 40, and 14).

\section{Type 2: Influencer as an Entertainer}

Type 2 consists of heavy YouTube users who mainly consume an influencer's content to entertain themselves and get instructions. This group uses social media, especially YouTube, to enjoy contents such as influencers' product reviews and "how to" videos (\#2). Therefore, Type 2 won't get bothered when influencers

Table 2. Eigen value and variance

\begin{tabular}{lcccc}
\hline & Type 1 & Type 2 & Type 3 & Type 4 \\
\hline Eigen value & 6.57 & 2.35 & 1.50 & 1.16 \\
Variance & 0.29 & 0.10 & 0.07 & 0.05 \\
Total variance & 0.29 & 0.39 & 0.45 & 0.50 \\
\hline
\end{tabular}

Table 3. Correlation between types of consumer

\begin{tabular}{lcccc}
\hline Type & Type 1 & Type 2 & Type 3 & Type 4 \\
\hline Type 1 & 1.00 & & & \\
Type 2 & 0.17 & 1.00 & & \\
Type 3 & 0.38 & 0.34 & 1.00 & \\
Type 4 & 0.35 & 0.22 & 0.25 & 1.00 \\
\hline
\end{tabular}

Table 4. Demographic information and factor weights by type

\begin{tabular}{|c|c|c|c|c|}
\hline Type & No. & Gender & Age & Weight \\
\hline \multirow{11}{*}{$\begin{array}{l}\text { Type I } \\
(\mathrm{N}=11)\end{array}$} & 1 & $M$ & 25 & 0.51 \\
\hline & 3 & $M$ & 27 & 1.06 \\
\hline & 6 & M & 24 & 1.36 \\
\hline & 7 & M & 26 & 0.71 \\
\hline & 9 & $\mathrm{~F}$ & 23 & 0.79 \\
\hline & 12 & $\mathrm{~F}$ & 24 & 1.06 \\
\hline & 13 & $\mathrm{~F}$ & 26 & 1.17 \\
\hline & 14 & $\mathrm{~F}$ & 22 & 0.49 \\
\hline & 15 & $M$ & 26 & 2.36 \\
\hline & 20 & M & 31 & 1.61 \\
\hline & 23 & $\mathrm{~F}$ & 40 & 1.00 \\
\hline \multirow{4}{*}{$\begin{array}{l}\text { Type II } \\
(\mathrm{N}=4)\end{array}$} & 4 & $M$ & 21 & 0.36 \\
\hline & 16 & $\mathrm{~F}$ & 23 & 0.63 \\
\hline & 17 & M & 24 & 1.84 \\
\hline & 19 & $M$ & 21 & 2.00 \\
\hline \multirow{6}{*}{$\begin{array}{l}\text { Type III } \\
(\mathrm{N}=6)\end{array}$} & 5 & $\mathrm{~F}$ & 21 & 0.73 \\
\hline & 8 & M & 24 & 0.53 \\
\hline & 10 & M & 24 & 2.45 \\
\hline & 11 & $\mathrm{~F}$ & 24 & 0.56 \\
\hline & 18 & $\mathrm{~F}$ & 24 & 0.74 \\
\hline & 22 & $\mathrm{~F}$ & 45 & 0.40 \\
\hline \multirow{2}{*}{$\begin{array}{l}\text { Type IV } \\
(\mathrm{N}=2)\end{array}$} & 21 & M & 21 & 1.15 \\
\hline & 24 & $\mathrm{~F}$ & 33 & 1.41 \\
\hline
\end{tabular}


use social media for marketing purposes (\#37). This group shows that an influencer they like can lead to positive images of a brand (\#44). For this, building trust between an influencer and its users is more important than using famous mega-influencers in marketing (\#46).

In addition, this group thinks that the pictures of food, places, products and services uploaded by influencers are "cool," which stimulate them to try these (\#17). Besides, an influencer's communication ability and persuasion strategies can promote consumers/followers' purchase intentions (\#25). Purchase intentions, however, do not lead to actual purchase actions. When it comes to actual purchase decisions, Type 2 tends to buy products/services from a brand that they get attracted to rather than from the reviews uploaded by influencers (\#30).

Besides influencers, Type 2 also uses information from laypeople on social media to learn more about products/services (\#18). Sponsorship disclosure also matters to Type 2. Type 2 is different from Type 1 in that this group is quite indifferent with influencer marketing if the sponsorship disclosure is clearly stated in the branded content. Type 2 says that even when an influencer excessively uses paid or sponsored contents, it would not negatively affect their perceptions toward the brand (\#38).

\section{Type 3: Influencer as an Information Source}

Type 3 sees influencers as a source of information that must be "credible" in their words and deeds. Type 3 expects influencers to be transparent in what they communicate to their audience. For this reason, Type 3 expressed adverse feelings toward an influencer who pretends to be an "expert" (\#10), and that it resulted in decreasing the consumer's trust in influencers (\#46) because their content is not perceived as authentic (\#20). For Type 3 , a brand does not need to use celebrities or mega-influencers to increase brand awareness or increase sales (\#27). Instead, the content uploaded by laypeople can still affect this group's purchase decisions (\#8) if the content is authentic and transparent.

In this vein, sponsorship disclosure is critical for Type 3 (\#28). While Types 1 and 2 also showed that sponsorship disclosure is important for influencers, Type 3 showed the highest Z-scores (2.29; Type $1=1.58$, Type $2=1.63)$ on this statement. Therefore, being persuasive refers to being transparent for Type 3, which can in turn affect Type 3's purchase intentions (\#25). In order to secure an influencer's transparency, Type 3 believes that there must be a legal framework for influencer marketing (\#41).

\section{Type 4: Influencer as My Tastemaker}

While the first three groups showed negative or neutral, at best, perceptions of influencer marketing, Type 4 showed positive perceptions of it. For Type 4, influencers are the tastemakers who affect their images and purchase intentions of products/ services ( $\# 44$ and 25). Rather than being attracted to the brand itself, purchase intentions of Type 4 are more affected by their preferred influencers who promote the brand (\#30). Thus, an influencer's persuasive abilities and skills affect this type's buying decisions (\#25). In addition, Type 4 even welcomes if their preferred influencers collaborate with a brand (\#45) and even launch their own brands (\#39).

While other types are concerned about an influencer being a shopping host because it makes the influencer appear less genuine, and focus too much on paid/sponsored content, Type 4 perceives it as okay when an influencer not only promotes but also sells a product to its users (\#34). Type 4 prefers Instagram over other social media platforms, especially YouTube. They do not enjoy watching product reviews or how-to videos on YouTube (\#1 and \#2). Instead, they perceive Instagram as more useful in gathering information on shopping (\#3). Thus, purchase intentions of Type 4 for a brand are affected by the influencer whom they "like" (\#44, 25, and 21).

\section{Consensus Statements}

Q methodology not only looks at the statements that distinguish one factor from another but also takes into account the statements on which all factors uniformly agree, disagree, or be neutral (Coogan \& Herrington, 2011). These statements are called consensus statements. One statement emerged on which all four factors positively agreed. All types agreed that although there are many ways to get information, the impact of influencers cannot be ignored nowadays ( $\# 23, \mathrm{Z}$ score $=1.11$ ).

\section{Discussion}

The findings of this study observed four different types of consumers based on their subjective perceptions of influencer marketing. The current study contributes to the literature on SMI marketing by investigating how consumers in South Korea perceive influencer marketing and how these subjective perceptions affect their attitudes and behavior intentions towards a brand that uses influencer marketing.

Findings indicate that Type 1 has the most negative perceptions of influencers because they regard influencers as nothing more than advertising tools who pretend to be genuine. As a result, Type 1 is skeptical of influencer marketing due to the commercial intent of influencers' messages (Perrey \& Spillecke, 2013). Therefore, advertising that explicitly reveals its marketing purposes would be more effective for this type.

For Type 1, such indicators as a high number of followers or views that may show the "power of an influencer" neither at- 
tracts them nor affects their buying behaviors. Instead, influencer marketing for Type 1 serves as a venue to introduce a (new) brand and increase brand awareness. In order to positively affect their buying intentions, a brand may use curated content marketing. As more brands are producing a massive amount of content about a given subject every day, consumers are, in fact, challenged to find quality information (Sebald \& Jacob, 2020). Therefore, besides publishing their own material, brands can curate contents from the best sources in the industry and deliver them to the consumers in a digestible format at a predictable time. This can not only offer direct contact with consumers but also save their time from searching for quality information.

Type 2 consists of heavy YouTube users. Similar to Type 1, Type 2 shows negative perceptions of influencer marketing. Results, however, observed subtle differences between Types 1 and 2. While Type 1 dislikes (and even hates) seeing sponsored content on social media, Type 2 shows a moderate level of negative perceptions of influencer marketing. Besides, Type 2 enjoys trying "things (e.g., food, places, products, services, etc.)" uploaded by influencers. This implies that influencer marketing, if strategically used, has the potential to lead a YouTube user to a consumer. As SMI content is one of the methods of getting entertained for Type 2, branded contents involving entertaining attributes can be a good way to expose brand names. One way to promote brands by entertainment embedded messages is to use user generated content (UGC) by YouTubers. Research suggested that UGC is perceived as more credible by younger generations (Mir \& Ur Rehman, 2013). In addition, the content made by generic YouTube users creates parasocial interaction, which results in favorable purchase intentions across various consumer groups (e.g., Hwang \& Zhang, 2018; Rasmussen, 2018; Sokolova \& Kefi, 2020).

Type 3 perceives influencers as a source of information, and therefore places importance on the influencer's transparency and sponsorship disclosure. In order to attract such consumers as Type 3, it is imperative for marketers to clearly disclose if the influencer's content is sponsored. Previous research has observed that the brand can be benefited from sponsorship disclosure. According to Nebenzahl and Secunda (1993), consumers showed positive attitudes towards product placements when the brand was transparent about it. Moreover, if a brand is transparent about the influencer's sponsored contents, then consumers may see that the influencer is highly valued by the brand, which can increase the marketing effectiveness (Pöyry et al., 2019). In addition, highlighting that a brand strictly adheres to influencer law with sponsorship, such as the FTC's guide for influencers and advertisers, can help persuade audiences that the brand is making efforts to communicate credible information.
Unlike Types 1 and 2, Type 4 shows positive perceptions of influencer marketing and even welcomes a brand's collaboration with an influencer. Type 4 is the only group who did not care about sponsorship disclosure of an influencer. Type 4 sees influencers as tastemakers and shows great support for influencers they "prefer." Thus, Type 4 is positively affected by these influencers when making buying decisions. Type 4 prefers Instagram to other social media platforms, such as YouTube, implying that they enjoy a clutter free user interface (Zejnilovic, 2018). For this type of consumer, it is recommended for a brand to use referral marketing on Instagram. While referral marketing is similar to word-of-mouth (WOM) in that both rely on consumer relationships, there is a subtle difference between the two. WOM occurs in a more natural setting, spreading stories from consumers to consumers. In referral marketing, however, a brand 'intentionally' encourages its loyal and satisfied consumers to share and spread marketing messages through their social contacts (Ghosh, Gaurav, Bhattacharya, \& Singh, 2020). More specifically, a brand can take advantage of Instagram users' sharing behaviors, providing them compensation when they make referrals based on either direct payment or increased visibility on social media (Berman, 2016). In addition, celebrity endorsement with previews of products or services coming to market is another strategy to help achieve marketing goals. It gives a consumer a sense of having privileges to insider information (Chen, 2017) and creates a sense of "intimate co-presence" (Hjorth \& Richardson, 2014). Enhancing a sense of exclusiveness and privilege among consumers can promote consumers' self-images and can promote consumers to share branded contents with their friends and families (John, 2013).

\section{Limitations of the Study}

There are two limitations in this study. First, the data was collected mainly from the participants in their twenties and therefore may not be applied to consumers across ages. Second, Q statements are pre-determined by researchers in this study and therefore may not fully capture the participant's views of the subject.

\section{Conclusion}

This study verified that consumers acknowledge the impact of influencers in digital marketing. Results, however, observed that authenticity of influencer marketing messages and trust between an influencer and its consumers are not the priorities for all consumer types. Consumers expect different values in influencer marketing depending on their social media preferences and subjective perceptions of influencers and marketing approaches. 
Besides demographics of consumers, such results can provide basic data for segmenting target audiences in influencer marketing. Furthermore, results suggest that using mega influencers with a high number of followers and views is not a panacea to achieve marketing goals. Instead, highlighting such messages as entertaining content, credibility, transparency, and explicit sponsorship disclosure in business efforts can help address a particular consumer group's values in influencer marketing.

\section{References}

Andrews, L., Drennan, J., \& Russell-Bennett, R. (2012). Linking perceived value of mobile marketing with the experiential consumption of mobile phones. European Journal of Marketing, 46(3/4), 357-386.

Balasubramanian, S. K. (1994). Beyond advertising and publicity: Hybrid messages and public policy issues. Journal of Advertising, 23(4), 29-46.

Berman, B. (2016). Referral marketing: Harnessing the power of your customers. Business Horizons, 59(1), 19-28.

Boush, D. M, Friestad, M., \& Rose, G. M. (1994). Adolescent skepticism toward TV advertising and knowledge of advertiser tactics. Journal of Consumer Research, 21(1), 165-175.

Brackett, J. (2012). People are 71\% more likely to purchase based on social media referrals. Business 2 Community. Retrieved from https://www.business2 community.com/social-media/ people-are-71-more-likely-to-purchase-based-on-social-mediareferrals-0126779

Brown, D., \& Hayes, N. (2008). Influencer marketing: Who really influences your customers? New York, NY: Taylor \& Francis

Brown, S., Kozinets, R. V., \& Sherry J. F. Jr. (2003). Teaching old brands new tricks: Retro branding and the revival of brand meaning. Journal of Marketing, 67(3), 19-33.

Byrne, E., Kearney, J., \& MacEvilly, C. (2017). The role of influencer marketing and social influencers in public health. Proceedings of the Nutrition Society, 76(OCE3), E103.

Campbell, M. C., Mohr, G. S., \& Verlegh, P. W. J. (2013). Can disclosures lead consumers to resist covert persuasion? The important roles of disclosure timing and type of response. Journal of Consumer Psychology, 23(4), 483-495.

Chae, J. (2018). Explaining females' envy toward social media influencers. Media Psychology, 21(2), 246-262.

Chen, H. (2017). College-aged young consumers' perceptions of social media marketing: The story of Instagram. Journal of Current Issues \& Research in Advertising, 39(1), 22-36.

Colliander, J., \& Erlandsson, S. (2015). The blog and the bountiful: Exploring the effects of disguised product placement on blogs that are revealed by a third party. Journal of Marketing Commu- nications, 21(2), 110-124.

Coogan, J., \& Herrington, N. (2011). Q-methodology: An overview. Research in Secondary Teacher Education, 1(2), 24-28.

Čop, N. G., \& Culiberg, B. (2020). Business is business: The difference in perception of influencer's morality between generation $\mathrm{Y}$ and Z. In F. Martínez-López, \& S. D’Alessandro (Eds.), Advances in digital marketing and eCommerce. Cham, Switzerland: Springer.

Cross, R. M. (2005). Exploring attitudes: The case for Q methodology. Health Education Research, 20(2), 206-213.

De Veirman, M., Cauberghe, V., \& Hudders, L. (2017). Marketing through Instagram influencers: The impact of number of followers and product divergence on brand attitude. International Journal of Advertising, 36(5), 798-828.

Dholakia, R. R., \& Sternthal, B. (1977). Highly credible sources: Persuasive facilitators or persuasive liabilities? Journal of Consumer Research, 3(4), 223-232.

Djafarova, E., \& Rushworth, C. (2017). Exploring the credibility of online celebrities' Instagram profiles in influencing the purchase decisions of young female users. Computers in Human Behavior, $68,1-7$.

Federal Trade Commission (2019, November). Disclosures 101 for socia media influencers. FTC. Retrieved from https://www.ftc.gov/tips-advice/ business-center/guidance/disclosures-101-social-media-influencers

Fransen, K., Haslam, S. A., Steffens, N. K., Vanbeselaere, N., De Cuyper, B., \& Boen, F. (2015). Believing in "us": Exploring leaders' capacity to enhance team confidence and performance by building a sense of shared social identity. Journal of Experimental Psychology: Applied, 21(1), 89-100.

Freberg, K., Graham, K., McGaughey, K., \& Freberg, L. A. (2011). Who are the social media influencers? A study of public perceptions of personality. Public Relations Review, 37(1), 90-92.

Friestad, M., \& Wright, P. (1994). The persuasion knowledge model: How people cope with persuasion attempts. Journal of Consumer Research, 21(1), 1-31.

Ghosh, S., Gaurav, K., Bhattacharya, S., \& Singh, Y. N. (2020). Ensuring the spread of referral marketing campaigns: A quantitative treatment. Scientific Reports, 10(1), 11072.

Hjorth, L., \& Richardson, I. (2014). Gaming in social, locative and mobile media. New York, NY: Palgrave Macmillan.

Hovland, C. I., Janis, I. L., \& Kelley, H. H. (1953). Communication and persuasion: Psychological studies of opinion change. New Haven, CT: Yale University Press.

Hwang, K., \& Zhang, Q. (2018). Influence of parasocial relationship between digital celebrities and their followers on followers' purchase and electronic word-of-mouth intentions, and persuasion knowledge. Computers in Human Behavior, 87, 155-173.

Hwang, Y., \& Jeong, S. H. (2016). This is a sponsored blog post, but all opinions are my own: The effects of sponsorship disclosure on 
responses to sponsored blog posts. Computers in Human Behavior, 62, 528-535.

Jang, Y. A., \& Kim, H. (2019). The effects of SNS characteristics and clothing shopping orientation on purchase intention of fashion products in Instagram market. Korean Journal of Human Ecolo$g y, 28(6), 629-642$.

John, N. A. (2013). Sharing and Web 2.0: The emergence of a keyword. New Media \& Society, 15(2), 167-182.

Kaikati, A. M., Kaikati, J. G. (2004). Stealth marketing: How to reach consumers surreptitiously. California Management Review, 46(4), 6-22.

Katz, E., Haas, H., \& Gurevitch, M. (1973). On the use of the mass media for important things. American Sociological Review, 38(2), 164-181.

Khan, M. L. (2017). Social media engagement: What motivates user participation and consumption on YouTube? Computers in Human Behavior, 66, 236-247.

Kirmani, A., \& Wright, P. (1989). Money talks: Perceived advertising expense and expected product quality. Journal of Consumer Research, 16(3), 344-353.

Lee, S., \& Kim, E. (2020). Influencer marketing on Instagram: How sponsorship disclosure, influencer credibility, and brand credibility impact the effectiveness of Instagram promotional post. Journal of Global Fashion Marketing, 11(3), 232-249.

Lu, L. C., Chang, W. P., \& Chang, H. H. (2014). Consumer attitudes toward blogger's sponsored recommendations and purchase intention: The effect of sponsorship type, product type, and brand awareness. Computers in Human Behavior, 34, 258-266.

McKeown, B. (2001). Loss of meaning in Likert scaling: A note on the Q methodological alternative. Operant Subjectivity, 24(4), 201-206.

McQuail, D. (1983). Mass communication theory: An introduction. London, UK: Sage.

Mediakix. (2021). 6 major influencer marketing scandals shaping the industry. Mediakix. Retrieved from https://mediakix.com/ blog/influencer-marketing-scandals-controversy/

Mir, I. A., \& Ur Rehman, K. (2013). Factors affecting consumer attitudes and intentions toward user-generated product content on YouTube. Management \& Marketing, 8(4), 637-654.

Moulard, J. G., Raggio, R. D., \& Folse, J. A. G. (2016). Brand authenticity: Testing the antecedents and outcomes of brand management's passion for its products. Psychology \& Marketing, 33(6), 421-436.

Mudambi, S. M., \& Schuff, D. (2010). What makes a helpful online review? A study of customer reviews on Amazon.com. Management Information Systems Quarterly, 34(1), 185-200.

Nebenzahl, I. D., \& Secunda, E. (1993). Consumers' attitudes toward product placement in movies. International Journal of Ad- vertising, 12(1), 1-11.

Oh, R. (2020, October 8). South Koreans' endless love for YouTube... 43 million people watch YouTube more than 30 hours per month. Chosun Ilbo. Retrieved from https://www.chosun.com/economy/ tech_it/2020/10/08/NK7R4EVGR5GNDB45RYDLXJ5RUE/

Ohanian, R. (1991). The impact of celebrity spokespersons' perceived image on consumers' intention to purchase. Journal of Advertising Research, 31(1), 46-54.

Paek, K. Y., Murthy, H. N., Hahn, E. J., \& Zhong, J. J. (2009). Large scale culture of ginseng adventitious roots for production of ginsenosides. Advances in Biochemical Engineering/Biotechnology, 113, 151-176.

Perrin, A., \& Anderson, M. (2019, April 10). Share of U.S. adults using social media, including Facebook, is mostly unchanged since 2018. Pew Research Center. Retrieved from https://www. pewresearch.org/fact-tank/2019/04/10/share-of-u-s-adultsusing-social-media-including-facebook-is-mostly-unchangedsince-2018/

Perrey, J., \& Spillecke, D. (2013). Retail marketing and branding: A definite guide to maximizing ROI. Hoboken, NJ: John Wiley \& Sons.

Pöyry, E., Pelkonen, M., Naumanen, E., \& Laaksonen, S. M. (2019). A call for authenticity: Audience responses to social media influencer endorsements in strategic communication. International Journal of Strategic Communication, 13(4), 336-351.

Rakuten Marketing. (2019). 2019 Influencer marketing global survey: Consumers. Rakuten Advertising. Retrieved from https:// rakutenmarketing.com/influencer-marketing-global-survey

Rasmussen, L. (2018). Parasocial interaction in the digital age: An examination of relationship building and the effectiveness of YouTube celebrities. The Journal of Social Media in Society, 7(1), 280-294.

Scott, D. M. (2015). The new rules of marketing and PR: How to use news releases, blogs, podcasting, viral marketing and online media to reach buyers directly (5th ed.). New York, NY: John Wiley \& Sons.

Sebald, A. K., \& Jacob, F. (2020). What help do you need for your fashion shopping? A typology of curated fashion shoppers based on shopping motivations. European Management Journal, 38(2), 319-334.

Seo, Y., Kim, S., \& Seo, Y. K. (2011). Exploring consumer types of low-cost carrier using Q methodology. Journal of Tourism Sciences, 35, 145-164.

Shinebourne, P. (2009). Using Q method in qualitative research. International Journal of Qualitative Methods, 8(1), 93-97.

Sokolova, K., \& Kefi, H. (2020). Instagram and YouTube bloggers promote it, why should I buy? How credibility and parasocial interaction influence purchase intentions. Journal of Retailing and 


\section{Consumer Services, 53.}

Solomon, M. R. (1996). Consumer behavior (3rd ed.). London, UK: Prentice Hall.

Song, S., \& Ko, E. (2017). Perceptions, attitudes, and behaviors toward sustainable fashion: Application of Q and Q-R methodologies. International Journal of Consumer Studies, 41(3), 264-273.

Stanton, J. V., \& Guion, D. T. (2010). Consumer attitudes toward organic foods: An exploration of U.S. market segments. In R. Belk (Ed.), Research in consumer behavior (pp. 5-41). Bingley, UK: Emerald.

Stephenson, W. (1967). The play theory of mass communication. Chicago, IL: University of Chicago Press.

Stubb, C., Nyström, A. G., \& Colliander, J. (2019). Influencer marketing: The impact of disclosing sponsorship compensation justification on sponsored content effectiveness. Journal of Communication Management, 23(2), 109-122.

Valenta, A. L., \& Wigger, U. (1997). Q-methodology: Definition and application in health care informatics. Journal of the American Medical Informatics Association, 4(6), 501-510.

van Reijmersdal, E., Fransen, M., Noort, G., Opree, S., Vandeberg, L., Reusch, S., ... Boerman, S. (2016). Effects of disclosing sponsored content in blogs: How the use of resistance strategies medi- ates effects on persuasion. American Behavioral Scientist, 60(12), 1458-1474.

Vannini, P., \& Franzese, A. (2008). The authenticity of self: Conceptualization, personal experience, and practice. Sociology Compass, 2(5), 1621-1637.

Wagner, A. (2017, May 15). Are you maximizing the use of video in your content marketing strategy? Forbes. Retrieved from https:// www.forbes.com/sites/forbesagencycouncil/2017/05/15/areyou-maximizing-the-use-of-video-in-your-content-marketingstrategy/?sh=33c6833c3584

Wiedmann, K. P., \& von Mettenheim, W. (2020). An adaptation of the source credibility model on social influencers: An abstract. In F. Pantoja, S. Wu, \& N. Krey (Eds.), Enlightened marketing in challenging times: Developments in marketing science: Proceedings of the Academy of Marketing Science. Cham, Switzerland: Springer.

Wiley, D. (2014). Why brands should turn to bloggers instead of celebrity spokespeople. Marketing Land. Retrieved from http://marketingland. com/brands-turn-bloggers-instead-celebrity-spokespeople-75971

Zejnilovicj, E. (2018, January 21). 3 Factors that make Instagram the best social media platform. Irish Tech News. Retrieved from https://irishtechnews.ie/3-factors-that-make-instagram-thebest-social-media-platform/ 